\author{
Agnieszka ALIŃSKA, PhD, Professor SGH \\ SGH Warsaw School of Economics \\ e-mail: aalin@sgh.waw.pl \\ ORCID: 0000-0002-6916-0761
}

\author{
Barbara WOŹNIAK, PhD \\ SGH Warsaw School of Economics \\ e-mail: bwoznia@sgh.waw.pl
}

DOI: $10.15290 /$ oes.2018.03.93.01

\title{
ANTI-CRISIS FINANCIAL ASSISTANCE AS AN ELEMENT OF FINANCIAL SYSTEM STABILITY
}

\begin{abstract}
Summary
Goal - The authors undertake to assess the scale and form of anti-crisis state assistance in the context of restoring the stability of the financial system in the EU. Such assistance is a form of intervention undertaken independently by EU Member States under the conditions of admissibility applicable in the EU. The applied instruments include: state aid (discussed in detail in this paper) and financial assistance on general terms applied in the form of unconventional instruments. The authors attempt to answer two basic questions: Was anti-crisis assistance necessary in the EU in order to maintain the stability of the financial system? What are the long-term consequences of implementing such measures at the EU level and in individual EU Member States?

Research methodology - The study uses the method of analysis of partial phenomena and identification of causal changes occurring in the financial system. On this basis, theoretical inference is carried out allowing to determine whether the anti-crisis measures used by EU financial policy have brought tangible results for the financial system and the real economy.

In order to formulate final conclusions, available statistical data and the results of research conducted on an international level are analyzed. Next, the current value of financial aid is estimated and the adopted assumptions and efficiency of the implemented instruments of state financial policy are analyzed and assessed.

Score - In view of the objective and scope of the conducted research, it is expected that the obtained results will allow the authors to identify the scale of public aid and the assistance provided in the form of unconventional financial policy instruments implemented during the global financial crisis. This approach will make it possible to perform an appraisal of the use of selected mechanisms for stabilizing the financial system. The conducted research should enable the authors to assess the impact of anti-crisis aid on the state of public finances and the stability of the market financial system.
\end{abstract}

Keywords: financial system, public aid, financial support, banking sector

JEL classification: H20, H50, H62, G22 


\section{Introduction}

The recent global financial crisis exposed numerous threats, disproportions, inequalities, and areas of the financial system which require the application of a new approach, reorganization, or even implementation of certain corrective activities. The scale of the financial crisis and its consequences for both the financial system and the real economy proved to be so significant that the emerging instability required launching radical and extensive aid programmes, usually supervised by state institutions (governments or central banks). They resorted to granting financial aid, in various forms and scopes, in order to restore the stability of the financial system, thus reducing the financial and social costs of the crisis, as well as to stimulate the processes which underpin economic growth and development. One of the forms of such aid is financial backing provided for companies (including financial institutions) under the conditions of admissibility specified in the Treaty on the Functioning of the European Union (TFEU), i.e. state aid (public aid).

The objective of this paper is to assess the scale and form of anti-crisis state aid in the context of restoring the stability of the financial system in the EU. Such aid is a form of intervention undertaken independently by EU Member States under the conditions of admissibility applicable in the EU, for instance, with the aim of restoring the stability of the financial system and the real economy, using public funds. In general, anti-crisis aid can be divided into two basic categories:

1. public aid,

2. financial aid under the terms and conditions laid down by the European Union.

The authors of this study focus solely on public aid given to financial institutions in the period of the recent global financial crisis, i.e. on selected mechanisms of stability of the financial system, mainly its market component.

\section{Financial system and factors of its stability}

Financial stability is a desirable, multi-aspect and complex state, indispensable for the proper functioning and development of every state's economy. However, it is a state which is very difficult to achieve and then maintain. The literature describes several theoretic mechanisms of preserving financial stability which proved efficient in the period preceding the global financial crisis. G. J. Schinasi [2016, p. 26] seems to have taken an appropriate approach to the issue in question, claiming that what is crucial for preserving financial stability is an accurate evaluation of the preset condition of the financial system. In the period preceding the global financial crisis, the stability of financial systems had been defined (cf. e.g., M. Iwanicz-Drozdowska [2014, pp. 3-16], A. Matysek-Jędrych [2014, pp. 9-18], M. Puławski [2012, pp. 113129], M. Capiga [2010] or P. Smaga [2014, pp. 18-26]) in two perspectives:

(1) as the state in which a financial system performs its functions in the economy, 
(2) as the situation in which financial crisis does not occur.

In the first perspective, attention should be paid to the following functions: monetary, capital, redistributive, and controlling (ascribed to the market side of the financial system) and such functions as: allocative, redistributive, and stabilising (ascribed to the public side of the financial system). From this perspective, financial stability can be defined as the state in which both parts of the financial system perform their functions in a continuous and effective way. From the other perspective, the stability of a financial system is perceived through the perspective of financial crisis, i.e. when no indication of an upcoming financial crisis is evident, the system is deemed stable. Such an approach requires defining the concept of 'financial crisis' with reference to both parts of the financial system.

Taking into consideration the two aforementioned perspectives of stability and the subject literature [Mitręga-Niestrój, 2014, p. 11], five basic states of a financial system can be identified:

- financial stability - when the system is resilient, properly and effectively performs its functions and role in the market, and attains its objectives,

- financial sensibility - when the system is characterised by increased vulnerability to both external and internal hazards, but continues to fulfil its functions,

- $\quad$ financial instability - when the system loses its resilience, owing to which its functional efficiency is impaired,

- financial crisis - when materialisation of risk occurs on a large scale in a system, as a result of which the system no longer performs its functions,

- $\quad$ stabilisation of the financial system - stabilisation mechanisms are activated when the areas of instability in the system have been identified and it is necessary to undertake corrective activities and implement non-standard (non-conventional) instruments.

Efforts to maintain the stability of a financial system ought to involve, above all, active participation of public institutions in creating systemic solutions, among which we can distinguish intra-systemic regulators and general solutions. The regulatory, supervisory, organisational, and legislative frameworks provide a basis for standard, effective and efficient functioning of the financial system as a whole and its particular (market and public) segments. These frameworks are defined both within individual countries and internationally, e.g. by the European Union, and may regard the use of public funds to grant financial backing to companies. Obviously, management of public funds is a domain of fiscal policy which in the EU is decided by individual Member States, but if it involves providing public aid, it falls into the scope of the common competition policy. 
CHART 1

\section{Stages of financial systems}

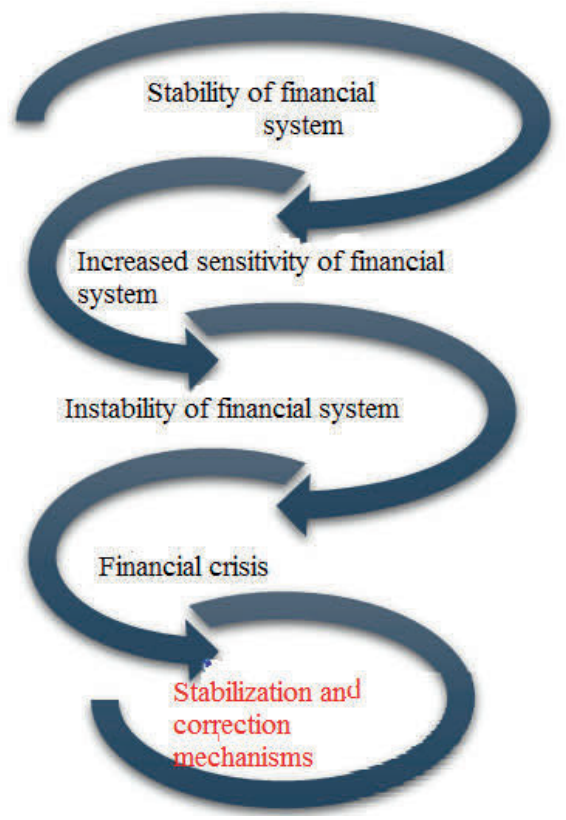

Source: author's own work.

The European Union pursues a common competition policy to protect the internal market from the disturbances caused, among other things, by activities undertaken by Member States in order to provide public aid to companies, which is a form of interference in the sphere of economic and social activity. ${ }^{1}$ State aid is aimed at stimulating positive economic and social processes or preventing negative phenomena, e.g. ones resulting from a crisis. Such activity of Member States impedes market competition and must be confined to solving the most important problems, in line with the mutual interest of the EU, and needs to be limited in temporal, sectoral and regional terms. The character and range of these limitations is laid down by the TFEU and numerous EU secondary laws [Woźniak, 2008, pp. 249250]. The control and monitoring of the state aid offered by particular EU countries are conducted by the European Commission (EC), which also prepares and implements the principles and procedures of providing aid under the common competition policy. ${ }^{2}$ The Commission cooperates with the European Council, EU Courts, and other organs which make decisions regarding EU policy on state aid.

1 The concept of state aid, pursuant to Article 107 (1) TFEU, and the rationale behind distinguishing it from other forms of state intervention, are specified in Commission Communication 2016.

2 The leading role of the Commission in the sphere of state aid is connected with its decisionmaking capacity as to what aid is admissible as compliant with the rules of the domestic market. 
Stra tegic documents of the EU define the future directions of this policy. In the years 2000-2010, the Lisbon Strategy was such a document, whereas currently, it is the Europe 2020 strategy, written already in the conditions of financial crisis. [Komunikat Komisji, 2010].

Similar to the Lisbon Strategy, Europe 2020 implies that public aid is aimed at removing market failures and inadequacies which prevent the implementation of specified priorities, adhering at the same time to the principle of "less and better targeted aid", which proposes a reduction of the amount of resources and a greater orientation towards horizontal, pro-development goals. ${ }^{3}$

Therefore, when a financial system is stable but finds itself in a state of increased sensitivity (chart 1), public aid is addressed mainly to non-financial entities, whereas there are visible signs of instability, the scope of aid provided to financial institutions increases in order to alleviate, mitigate, or eliminate the emerging disturbances and imbalances. If a financial crisis does occur, however, it is necessary to launch additional, wide-ranging measures to stabilize the financial system, including extraordinary (non-conventional) instruments of financial aid. This happens, for instance, when a public financial system within the frameworks of state fiscal policy, the EU competition policy, and public aid policy, offers assistance measures and aid funds to the banking sector (market financial system) in order to restore its stability and help it emerge from the crisis. Simultaneously, public support is targeted at the real economy, both before the financial crisis and throughout its duration, in accordance with the principles specified in EU legislation.

\section{Admissibility of public aid: the principles}

The treaty principles regarding the admissibility of state aid in the EU are defined in such way as to take into consideration both the needs of steadily developing economies and the necessity to provide support in special situations when signs of imbalance or instability appear. Nevertheless, the principles do not directly refer to the stability/instability of the financial system, but imply what the purposes of development aid and anti-crisis aid should be.

In accordance with Article 107 (3) (b) TFEU:

- development aid is "aid to promote the execution of an important project of common European interest", whereas

- anti-crisis aid is "aid to remedy a serious disturbance in the economy of a Member State."

Taking into consideration the recommendations to restrict the scale of public assistance, these definitions are very general and inclusive, both as regards development aid and anti-crisis aid. However, it can be assumed that the most widespread

3 It is worth emphasizing that the purpose of state aid is to eliminate market imperfections related, e.g., to the occurrence of external effects, and not to replace market mechanisms with public subsidies. State aid should play only a supplementary role. 
and transparent type of development aid is support provided by means of active instruments (e.g. subsidies), addressed to beneficiaries with good development prospects, but whose activity would not focus on horizontal objectives (e.g. R\&D), environmental protection, or regional aid (e.g. new investment projects) without financial backing from the public sector. Obviously, in the case of horizontal aid, the funds allocated to either rescuing or restructuring of enterprises do not constitute development aid but, along with sector aid, are the main forms of anti-crisis assistance [Jurkowska-Gomułka, 2014, p. 97].

Anti-crisis assistance is related to supporting companies which are either in a bad financial situation or face the risk of closure owing to the "disturbance in the economy of a member state". The exact meaning of "disturbance" is not defined in TFEU, but can be inferred, e.g., from the Commission's guidelines on the principles of offering aid for such enterprises. ${ }^{4}$

In accordance with the principle of subsidiarity, the Member States are responsible for the fiscal and economic policies they conduct and for the use of public aid instruments within the constraints imposed by the EU law (admissibility principles, notification principles, group exclusions). They make a choice between the two types of support: anti-crisis and development, taking into account the initial situation of the beneficiaries and the admissibility principles provided by the EU law.

The first instances of crisis-related state aid granted to financial institutions took place in 2007 and at the beginning of 2008. They concerned, among others, two German banks: Sachsen LB (the so-called Landesbanken, LB) and West LB, which had invested in American subprime securities, two banks in Great Britain: Northern Rock and Bradford \& Bingley, as well as the Danish Roskilde Bank. In these cases of individual aid given to banks, the Commission made prompt decisions allowing for state aid on the basis of the 'classical' principles of anti-crisis aid (Art. 107 (3) (b) TFEU), applicable to enterprises in difficulties. While making this decision, the Commission took into consideration the domino effect, assuming that those banks were "too big to fail" because their collapse would have caused panic in the retail savings market if depositors had begun to withdraw their savings en masse, after their trust in banks had been undermined [Lowe, 2009].

The Commission could not remain indifferent to the mounting threats to the financial systems of the Member States, which disrupted their stability and concerned mainly the banking sector. As it has the authority to control state aid, the Commission began to introduce special rules regarding state aid in the form of secondary legislation acts, mainly communications, without actually suspending or changing the regulations which had previously been in force.

Initially, it was assumed that the crisis would not last long, so regulations were promptly drafted to enable the application of instruments 'tailored' to the situation

4 Two groups of recommendations are in force at present: the first one (Commission Communication 2013, also referred to as 'Bank Communication') regards financial institutions; the second one (Commission Communication 2014) regards other enterprises, excluding enterprises from the coal and steel sector. 
of crisis. When the crisis persisted and it was impossible to predict when it would end, the principles of providing anti-crisis aid began to be ordered, supplemented, and prolonged. In the years 2008-2013, the Commission issued as many as seven communications. The first three (one of 2008 and two of 2009) regarded rescue aid to financial institutions, whereas the fourth one (the last of the 2009 communications) concerned aid for restoring the viability of banks and their restructuring. The adopted regulations were temporary, and only in the case of the fourth communication the expiry date was specified as the end of 2010. The next two communications regarded regulations which prolonged and updated the earlier settlements until the period starting on $1^{\text {st }}$ January 2011 (Communication 5 of 2010) and after $1^{\text {st }}$ January 2012 (Communication 6 of 2011). However, the last of them, the Commission's Communication of 2013 ('Banking Communication'), replaced the first Commission's Communication of 2008, introducing necessary changes and supplements integrating the previous regulations.

The issued communications permitted providing state aid to financial institutions in the form of the following instruments:

- government guarantee programmes,

- liquidity measures other than guarantees,

- recapitalisation of financial institutions, and

- interventions related to impaired assets.

\section{Instruments and scale of state aid during financial crisis}

The analysis of available and applied measures and mechanisms of stabilising the situation in the financial sector makes it possible to identify two main sources of anti-crisis aid, and namely:

1. undertaken actions and applied instruments classified as public aid,

2. other methods and forms of supporting the stability of the financial system, not classified as public aid, but addressed to private financial institutions.

The use of extraordinary instruments of anti-crisis aid caused a substantial increase in the overall amount of assistance offered. Initial estimates show that already at the beginning of the 2008 financial crisis the total value of aid (to financial institutions and the real economy) included in the support measures used in the EU reached $€ 279.6$ bln, i.e. $2.2 \%$ of GDP, which was almost five times more than in 2007 , when the value of aid amounted to $€ 65$ bln and constituted less than $0.5 \%$ of GDP. The first phase of the crisis was the most dangerous to the stability of the entire financial system because of the risk of a potential contagion effect and the impact on the real sphere of the economy.

Recapitalization of European banks during the global financial crisis and the follow-up crisis connected with the debt of the public sector in relation to GDP. Direct costs associated with the scale of financial aid for bank systems differ across countries. The differences result mainly from the scope and consequences of the crisis as well as from the size of the bank system in each country [Hüttl, Wolf, 2016]. 
Recapitalization of the Irish bank system constituted approx. $40 \%$ of the country's GDP, whereas in France, governmental support of the banking sector did not exceed $1.4 \%$ of the GDP. Four countries with the highest recapitalization costs (Ireland, Greece, Slovenia, and Cyprus) needed additional external aid from the IMF and the EU, whereas Belgium and Spain used approximately 8\% of their GDPs for recapitalization [Hüttl, Schoenmaker, 2016].

It must be pointed out that not all the EU countries provided anti-crisis aid to their financial institutions. These were: Bulgaria, Czech Republic, Estonia, Malta, Romania, and Slovakia, whereas Poland and Lithuania granted aid only in the form of recapitalization. Italy, Sweden, and Cyprus supported their banks with recapitalization and guarantees, whereas Finland - only with guarantees. Other countries provided assistance in all these forms.

CHART 2

Value of aid to financial system as \% of GDP in selected countries

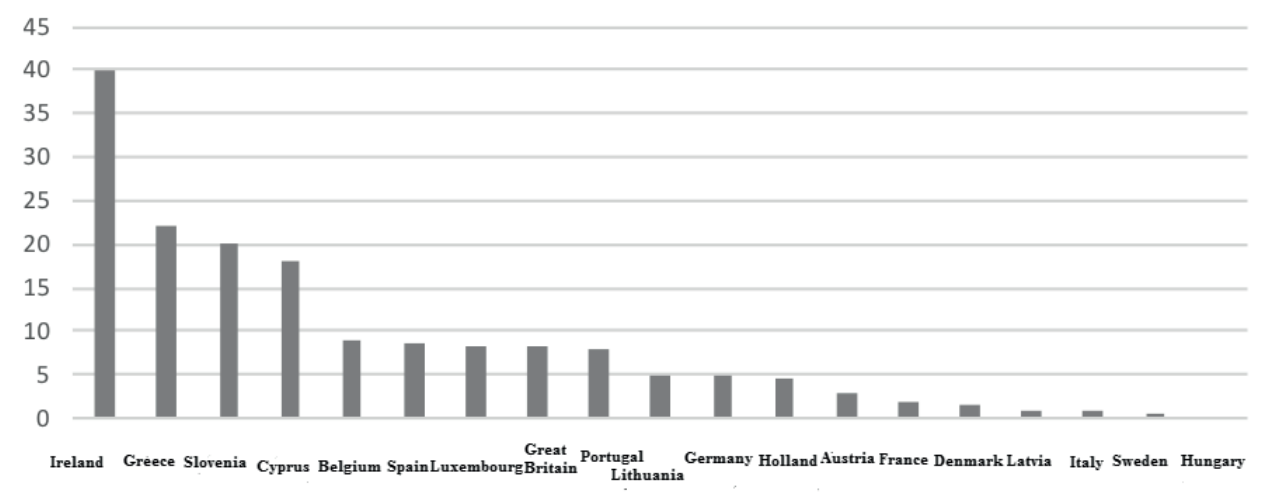

Source: [Hüttl, Schoenmaker, 2016].

The largest amount of public aid received in the form of guarantees ( $€ 835.8 \mathrm{bln}$ ) was addressed to financial institutions in 2009 and constituted $6.8 \%$ of the EU's GDP. In that year, the largest sum of aid in the form of guarantees was granted in Ireland $-€ 284.3$ bn (167.8\% of the country's GDP), ${ }^{5}$ Great Britain provided guarantees amounting to $€ 158.2 \mathrm{bln}$, which constituted $9.5 \%$ of its GDP, and Denmark - €145 bln, $60.1 \%$ of its GDP. ${ }^{6}$ As can be seen, the scale of aid ought to be referred

5 In 2010, the value of aid programmes granted in this country in the form of guarantees exceeded the value of the GDP (118.1\%), only in 2011 falling below the value of the GDP. In 2011, it constituted $63.5 \%$ of GDP, in $2012-47.8 \%$, in $2013-20.7 \%$, whereas in 2014 , only $5.6 \%$. In the years 2008-2014, in no other EU Member State aid in the form of guarantees exceeded the value of that country's GDP.

6 All the data concerning state aid are cited after Eurostat and Commission Reports. They concern utilised aid. 
to the size of the country and the GDP it generates. Only then is it possible to properly assess its impact on the country's financial situation.

At the end of 2009, a gradual withdrawal of extraordinary measures began, starting from curtailment of guarantee programs, with the aim of reducing the dependence of financial institutions on public aid and encouraging them to achieve liquidity in the market.

\section{Structure of anti-crisis aid according to instruments}

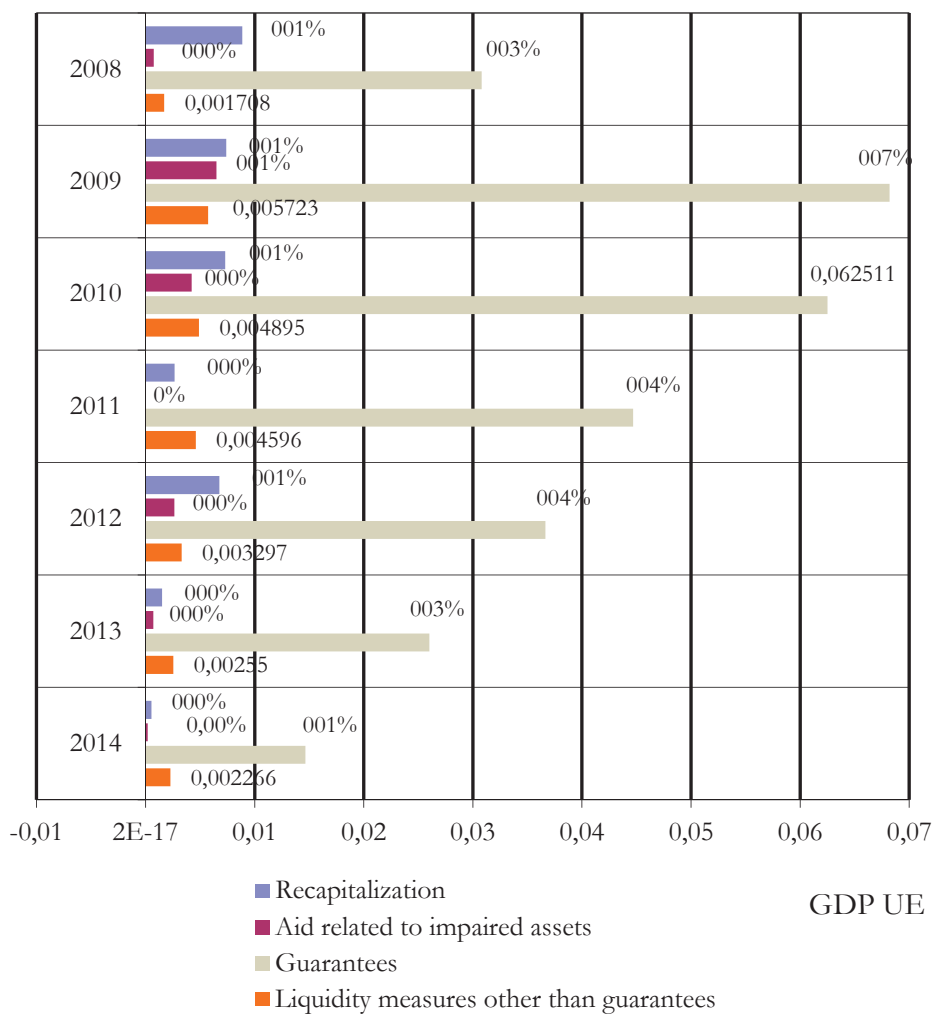

Source: author's own work on the basis of data available on: [ECB, 1010].

In the first years of the crisis, the Commission accepted this kind of assistance measures in order to restore trust in banks and activate the inter-bank market. ${ }^{7}$ However, the extension of support on such a scale was not justified, for instance,

7 It needs emphasising that the sum of guarantees used in 2008 ( $€ 400.1 \mathrm{bn}$ ) constituted only $13 \%$ of the aid authorised in this form by the Commission. Hence the potential possibilities of securing liquidity in the banking system were huge and could have a positive impact on restoring confidence in the banking sector and financial markets. 
because some banks used guarantees for structural reasons. Steps taken to restrict the use of this instrument already in 2010 resulted in a decrease in the amount of aid offered in the form of guarantees by $€ 36.0 \mathrm{bln}$. In the entire period of 2008-2014, not all countries took advantage of this most valuable form of assistance. Guarantees were not granted in: Bulgaria, Czech Republic, Estonia, Croatia, Lithuania, Malta, Poland, Romania, or Slovakia.

Liquidity measures other than guarantees accounted for a far smaller proportion of anti-crisis public aid. In 2008 , they amounted to $€ 22.2 \mathrm{bln}$, to reach their peak in 2009 ( $€ 70.1$ bln, i.e. $0.6 \%$ GDP in the EU) and gradually diminish in the subsequent years. These measures were not activated by 16 EU Member States, including Poland. On the other hand, considerable sums of public aid were allocated to the recapitalization of financial institutions - in total €453.3 bln in the years 2008-2014, i.e. $0.5 \%$ of the EU's GDP generated in that period. However, the most substantial aid in this form, i.e. €115.2 mln was granted in 2008. In the following years, the value of recapitalization decreased, while in 2014, it only amounted to $€ 7.6 \mathrm{bn}$. Undoubtedly, this was associated with the fact that the Commission's Communication 1 of 2008 adopted the principle that anti-crisis aid must be limited to the necessary minimum and needs to be strictly targeted and proportional. This principle was specified in the Commission's Communication 2 of 2009, which concerned the recapitalization of financial institutions and was reinforced after the mechanisms against excessive interference in competition had been defined. It was also then that payments for involvement of national capital were diversified, according to the principle that essentially healthy banks should pay less, while specific payment thresholds are based on the recommendations of the European Central Bank. In order to ensure efficient methods to wean economies off capital support from financial institutions, it was recommended that the value of the repayment of principal be increased in each subsequent year of receiving aid and that mechanisms be established to guarantee the correct use of the measures depending on the bank's risk profile. The precautions could be included in the trade policy, e.g. the ban on mergers and takeovers over a certain time period, in the policy of reducing executive salaries, or the policy of restrictive principles regarding the payment of dividends.

Furthermore, in the Commission Staff Working Paper, 2011, ${ }^{8}$ the EC presented the results of its assessment of the effects of introducing temporary rules governing state aid by means of all the instruments of anti-crisis assistance in three areas: financial stability, the functioning of the financial sector, and competition.

In the following years, the financial system in EU Member States was unstable. The tensions in financial markets and the economic recession persisted, as did the associated risk of disturbances in the economies of the Member States. Therefore, the Commission had to take a position on whether to maintain the special rules of public aid for financial institutions or whether to establish new ones. For this pur-

8 Previously, in April 2010, the European Central Bank had published the ECB's Report 2010, assessing aid activities in the Euro area. 
pose, in 2013 the Commission issued a new Communication 2013 ('Banking Communication'), which, among other things, adjusts and supplements the decisions of previous communications regarding recapitalization and impaired assets. The complex procedures associated with receiving such forms of assistance limited their availability.

Most EU states (twenty) used recapitalization as an instrument of anti-crisis aid. In the years 2008-2014, the most substantial funds were allocated for recapitalization in the following countries: Ireland (5.1\% of GDP), Spain ( $0.8 \%$ of GDP), Great Britain ( $0.7 \%$ of GDP), and Germany ( $0.3 \%$ of GDP).

In the same period, state aid related to the impairment of assets was lower: $€ 188.5$ bln, i.e. $0.2 \%$ of the EU's GDP. This instrument was used by twelve EU countries, while the highest expenditure on this purpose was made by Germany (€80 bln), Great Britain ( $€ 40 \mathrm{bln})$, and Spain ( $€ 32,9$ bln). These measures of state aid together with recapitalization within seven years reached the value of $€ 641.8$ bln $(0.7 \%$ of the EU's GDP in that period), which was less than the sum of guarantees granted both in 2009 and 2010.

\section{Conclusion: assessment of anti-crisis aid}

The analysis of the aid given to financial institutions in the European Union during the crisis shows that government guarantees, i.e. instruments most secure from the point of view of balance/stability of public finances, were the most prevalent form of support. Guarantees do not result in a flow of public funds to the beneficiaries, but only help strengthen their market position. What is more, the lack of necessity to mobilize funds from the guarantee may help generate financial resources from the interest rate for the guarantee and, as a consequence, can boost the revenues of the general government sector. For example, in the years 2010-2014, the revenues from guarantee charges in each EU state were higher than the expenditure associated with the granted guarantees and the general government sector of EU Member States 'earned' $€ 29.3$ bln. From the perspective of the impact on this sector's financial result, the use of guarantees as an instrument of anti-crisis aid can thus be assessed as positive.

Therefore, the above-presented structure of the forms of public aid granted to financial institutions during the recent crisis was not the main reason for the worsening of the balance (stability) of the public finances in the entire EU. However, the scale of the burden of aid may have certain consequences in the future. This may primarily concern the necessity to increase financial expenditures on preserving the stability of not only the market financial system, but also of the public finance sector.

The relief efforts connected with the financial crisis and using special measures of anti-crisis aid caused a substantial increase in financial support, but proved to be efficient. This is due to the fact that they made it possible to improve liquidity in the interbank market, restore financial stability and trust in financial institutions, and 
triggered signs of economic recovery. Nevertheless, they had a negative influence on the state of public finances in many countries because having placed a considerable strain on public resources, they caused a destabilization of public finances and contributed, e.g., to a higher deficit of the general government sector and increased public debt.

In the years 2010-2014, anti-crisis aid deepened the deficit of the general government sector of the European Union by $€ 165.8$ bln, whereas its impact on public debt remained at the level of approx. 5\% of GDP annually. In 2010 and 2012, anticrisis aid had the largest impact on the debt of this sector, increasing it by $€ 705.8 \mathrm{bln}$ and $€ 77.8$ bln, respectively. Obviously, in particular Member States the effects of provided aid were different. In several countries (Denmark, Italy, Sweden, Luxemburg, France, and Hungary), the impact anti-crisis aid on the result of the general government sector was even positive. In the successive years of the crisis, a decreasing impact of public aid on the deficit of the general government sector and public debt could be observed. It is a symptom of the positive impact of the granted aid on the stability of the financial system, including maintaining the security of the banking sector. Taking into consideration the increase in gross commitments in the economic system, public interventions in the financial sector caused an increase in the public debt of the euro area by approximately $4.8 \%$. Nevertheless, it should be emphasised that the final cost of aid for the financial sector has not been fully estimated because the restructuring processes of many financial institutions have not been completed.

\section{References}

Capiga M., Gradoń W., Szustak G., 2010, Sieć bezpieczeństwa finansowego, CeDeWu Platinium, Warszawa.

Commission Staff Working Paper, 2011, The effects of temporary State aid rules adopted in the context of the financial and economic crisis (SEC (2011) 1126 final, Brussels, 5.10. 2011).

ECB, 2010, Measures taken by Euro Area governments in support of the financial sector, "ECB Monthly Bulletin", April, https://www.ecb.europa.eu/pub/pdf/mobu/mb201004 en. pdf.

Hüttl P., Wolf G., 2016, Bruegel Dataset on State Aid to Banks', Working Paper, Bruegel.

Hüttl P., Schoenmaker D., 2016, Fiscal capacity to support large banks, Bruegel, Policy Contribution Issue 17.

Iwanicz-Drozdowska M., 2014, Definicje i determinanty stabilności finansowej, [w:] Stabilność finansowa, Iwanicz-Drozdowska M. (red.), Bank i Kredyt, Warszawa.

Jurkowska-Gomułka A., 2014, Wsparcie antykeryyysowe cay prorozwojowe: dylematy unijnej polityki pomocy publicznej, [w:] Rola sektora publicznego w okresie krysysu, Piątek S. (red.), Wydawnictwo Naukowe Wydziału Zarządzania UW, Warszawa.

Komunikat Komisji, 2008, Zastosowanie zasad pomocy panstwa do środków podjetych w odniesieniu do instytuciji finansonych w kontekśsie obecnego, globalnego krysysu finansowego, Dz. Urz. UE 2008/C 270/02. 
Komunikat Komisji, 2010, Europa 2020 - Strategia na rzecz. inteligentnego i zrównoważonego rozwoju sprayjajacego właczeniu spotecznemu (COM (2010) 2020, wersja ostateczna, Bruksela 3.03.2010).

Komunikat Komisji, 2013, w sprawie stosowania od dnia 1 sierpnia 2013 r. regut pomocy państwa w odniesieniu do środków wsparcia na rzecz banków w kontekśsie kryzysu finansowego („komunikat bankowy”), Dz. Urz. UE 2013/C 216/01.

Komunikat Komisji, 2014, Wytyczne dotyczqce pomocy państwa na ratowanie i restrukturyzacje przedsiebiorstw niefinansowych znajdujacych sie $w$ trudnej sytuacji, Dz. Urz. UE 2014/C 249/01.

Lowe Ph., 2009, State Aid Policy in the context of the financial crisis, "Competition Policy Newsletter", no. 2, http://ec.europa.eu/competition/publications/cpn/cpn_ 2009_2.html

Matysek-Jędrych A., 2014, Odpowiedzialnośc i przejryystość banku centralnego w działaniach na rzecz stabilności finansowej, „Materiały i Studia” z. 303.

Mitręga-Niestrój K., 2014, Niestabilność finansowa i jej źródta we współczesnym świecie, [w:] Zarzqdzanie instytucjami finansowymi w niestabilnym otoczeniu gospodarczym, Capiga M., Szustak G. (red.), „Studia Ekonomiczne”, nr 171.

Polański Z., 2008, Wprowadzenie. System finansowy we wspótczesnej gospodarce rynkowej, [w:] System finansowy w Polsce, Pietrzak B., Polański Z., Woźniak B. (red.), t. 1, Wydawnictwo Naukowe PWN, Warszawa.

Puławski M., 2012, Odpowiedzialność banków centralnych za stabilność finansowa, [w:] Wspótczesna bankowość centralna, Jaworski W.L., Szelagowska A. (red.), CeDeWu Platinum, Warszawa.

Schinasi G.J., 2006, Understanding Financial Stability: Towards a Practical Framework, Seminar on Current Developments in Monetary and Financial Law, Washington, D.C., October 23-27.

Smaga P., 2014, Rola banku centralnego w zapewnianiu stabilności finansowej, CeDeWu Platinum, Warszawa.

Sprawozdanie Komisji, 2009, Tabela wyników w dziedzinie pomocy państwa, Aktualizacja z jesieni 2009 r. (COM (2009) 661, wersja ostateczna, Bruksela 7.12.2009).

Woźniak B., 2008, Pomoc publiczna, [w:] System finansowy w Polsce, Pietrzak B., Polański Z., Woźniak B. (red.), t. 2, Wydawnictwo Naukowe PWN, Warszawa.

Zawiadomienie Komisji, 2016, w sprawie pojecia pomocy państwa w rozumieniu art. 107 ust. 1 Traktatu o funkcjonowaniu Unii Europejskiej, Dz. Urz. UE 2016/C 262/01. 